AGRARIS: Journal of Agribusiness and Rural Development Research

Vol. 6 No. 2: July-December 2020

Article history:

Submitted: September $7^{\text {th }}, 2020$

Accepted: November $18^{\text {th }}, 2020$
Oki Wijaya ${ }^{1 *}$, Widodo ${ }^{1}$, Riskhi Lathifah' ${ }^{1}$, Nur Rahmawati ${ }^{1}$, Cahyo Wisnu Rubiyanto ${ }^{2}$

${ }^{1}$ Department of Agribusiness, Faculty of Agriculture

Universitas Muhammadiyah Yogyakarta, Indonesia

2 United Graduate School of Agricultural Science, Gifu University, Japan

*) Correspondence email: okiwijaya@umy.ac.id

\title{
Household Dietary Patterns in Food Insecurity Areas
}

DOI: https://doi.org/10.18196/agr.6298

\begin{abstract}
Dietary contributes to sustainable food security. Accordingly, attempts to elevate dietary patterns should be simultaneous and comprehensive, especially to the farmer community living in rural areas, who have two roles, i.e., producers and consumers. In response to that situation, this research aims to analyze household dietary patterns and contributing factors. This research was conducted in Wukirsari, Imogiri, Bantul. The data used in this research were primary data collected from 63 respondents selected using the cluster sampling approach. Dietary patterns were analyzed using $2 \times 24$-hours dietary recall data with a household measure unit and a Desirable Dietary Pattern (DDP). Meanwhile, the contributing factors were analyzed using the Double Linear Regression Approach. Findings indicate that the Desirable Dietary Pattern in Wukirsari was monotonous, confirmed by the resulted DDP score of 60.62. Moreover, the significant factor with a partial impact on household dietary patterns was educational levels. Meanwhile, other factors, e.g., the number of family members, the age of the head of the family, income per capita, rice prices, beneficiaries, and the main job of the head of the family had a simultaneous significant impact, which was also partially insignificant, on dietary patterns.
\end{abstract}

Keywords: Dietary Pattern, Food Insecurity, Household, Energy Adequacy Level

\section{INTRODUCTION}

Food, as one of the primary needs, has been always one of the most spotlighted issues (Kuzmin, 2016). Also, it has a big and significant portion of the sustainability of a nation. Once the national food resilience is disrupted, social and political turmoil will inevitably happen and harm the national economic stability (Badan Urusan Logistik [The Indonesia Logistics Bureau], 2018).

Talking about food resilience, it is not only about food provision and price or food self-sufficiency (Badan Urusan Logistik [The Indonesia Logistics Bureau], 2018). Rather, food resilience is also a condition in which physical and economic access to healthy and nutritious food can be acquired anytime (Food and Agriculture Organization, 2007). Food resilience, as mentioned in Law Number 18 of 2012 on Food, is the condition of the fulfilment of food for the state and the individual, which is reflected by food availability which is adequate in terms of either its number or quality, secure, nutritious, equally distributed, and affordable, without violating the religion, belief, and culture held by the society, to sustainably live healthily, actively, and productively (Badan Urusan Logistik [The Indonesia Logistics Bureau], 2018). 
Issues in national food resilience remain unsolved if similar issues at the lowest level (household) are still there. One of the effective strategies to manifest household food resilience is to enhance food diversification (Saputra et al., 2019). Dietary pattern rectification is a long concern, and the government has made some attempts in regard to it, one of which is the Presidential Instruction (Inpres) No. 20/1974, which was perfected with the issuance of Inpres No. 20 of 1979 on Diversification of People's Diets and Improvement of Community Nutrition (Andri, 2019). However, Indonesia has homogenous dietary patterns which are also unbalanced in terms of nutrition, and the per food consumption is predominated by food with a high carbohydrate level. Besides, the Desirable Dietary Pattern (DDP) in Indonesia is not considered ideal, where the Energy Adequacy Level identified in Indonesia was $90.4 \mathrm{kcal}$ in 2017 (Saputra et al., 2019).

Research findings indicate several factors which affect household expenditure on food, e.g., income, sex, age, marital status, domicile, and occupational status (Kostakis, 2014). Besides, an increase in food commodity prices also brings about a decline in the demand for the commodity (Riyani et al., 2018).

On the National Workshop on Food and Nutrition Seminar (Widyakarya Nasional Pangan dan Gizi Seminar) in 2012, the government stipulated the target of achieving an output of food improvement, which was achieving the daily average energy consumption by 2,150 kcal/capita/day (Badan Ketahanan Pangan [The Food Security Bureau], 2017). To achieve the target, food dietary pattern improvement should be simultaneously implemented, starting from rural areas by concentrating on household behaviors, including farmer households as food producers and consumers (Food and Agriculture Organization of the United Nations, 2020). Furthermore, it is notified that the most susceptible community to food insecurity is poor households who live in rural areas. According to the data from Statistics Indonesia in 2019, 15.15 million poor people lived in rural areas, with food expenditure contributing to the poverty line by $73.66 \%$ (Badan Pusat Statistik [The Central Bureau of Statistics], 2017).

One of the food insecurity villages is located in Wukirsari, Imogiri, Bantul, Yogyakarta Special Region (Badan Ketahanan Pangan dan Penyuluhan DIY [The Food Security and Extension Bureau DIY], 2016). Based on the administrative map, Wukirsari Village has $15,385.504$ hectares with 16,837 people. The village is an arid area which only relies on rainfed rice fields, so the farmers can only plant the rice once a year. Wukirsari is located far from the growth center or district or province. Such geographical conditions affect the livelihoods and various aspects of the socio-economic life. Most of the people who work as farmers only depend on nature for their livelihoods. The low level of farmers' income is one of the factors that can affect household food dietary patterns. Most of the household's food dietary habits is used to fulfill the needs of carbohydrates. Meanwhile, other nutritional needs such as protein, minerals and vitamins are still less. Based on the research background, accordingly, this research aims to analyze household dietary patterns and the factors. 


\section{RESEARCH METHOD}

The research was conducted in Wukirsari, Imogiri, Bantul. The location was selected on purpose by considerating that the village is one of the food insecurity areas in Special Region of Yogyakarta (Badan Ketahanan Pangan dan Penyuluhan [The Food Security and Extension Bureau DIY] DIY, 2016). The data used in this research were primary data with sampling method by using a cluster sampling approach. The sampling technique was carried out randomly to 97 groups of Households in Wukirsari. The results determined that the sample was in Neighbourhood Committee 2 Dusun Nogosari, with a total of 63 households as the respondents.

\section{The Analysis of Dietary Patterns}

The analysis of food dietary patterns was carried out using food recall data of $2 \times 24$ hours with household measure unit. The data is then tabulated depends on the foodstuffs types, namely grains, tubers, animal foods, fatty oils, oily fruits/seeds, nuts, sugar, vegetables/fruit and others.

The energy contained by each food consumed is quantified using the following formula (Sirajudin et al., 2018):

$$
E j=(B j \times K e j / 100 \times(B D D j / 100)): J R T
$$

Description:

$\mathrm{Ej} \quad=$ the actual energy consumed from the food $\mathrm{j}(\mathrm{kcal} / \mathrm{cap} /$ day $)$

$\mathrm{Bj} \quad=$ the weight of the food $\mathrm{j}$ (gram)

Kej $\quad=$ the energy content per 100 gram of the food $j$

$\mathrm{BDD} j=$ the percentage of the food $\mathrm{j}$ which is consumable (\%BDD)

JRT = the number of household members (person)

$\mathrm{j} \quad=$ the food

To identify the energy content in the food $(\mathrm{Kej})$ and the percentage of food which is consumable (\%BDD) in the respective types of food, we can refer to the List of Food Ingredients (Daftar Komposisi Bahan Makanan - DKBM) and the List of Food Nutritional Content (Daftar Kandungan Gizi Makanan - DKGM). From the quantification result of energy contained by each food, we can quantify the total energy contained by the respective food groups using the following formula.

$$
\mathrm{Ep}=\sum_{j=1}^{m} E j p
$$

\section{Description:}

$\mathrm{Ep} \quad=$ the total actual energy in the food group $\mathrm{p}$

Ejp $\quad=$ the energy from the food $\mathrm{j}$ which belongs to the food group $\mathrm{p}$

$\mathrm{p} \quad=$ the food group, 1

$\mathrm{j} \quad=$ the food $1,2, \ldots, \mathrm{m}$

Quantification of total energy consumed is then conducted by adding up the results of energy quantification for each food group.

$$
\mathrm{TE}=\sum_{p=1}^{9} E p
$$


Description:

TE = the total actual energy identified in the aggregate food group

$\mathrm{Ep} \quad=$ the total actual energy in a food group

$\mathrm{p} \quad=$ the food group $1,2, \ldots, 9$

The Energy Adequacy Ratio (EAR) which is referred to as the normative standard energy adequacy level was $2,150 \mathrm{kcal} / \mathrm{cap} /$ day. Moreover, the energy percentage can show the energy which has been contributed by each of the food groups. It can be identified using the following formula:

$$
\mathrm{Pp}=(\mathrm{Ep} / \mathrm{EAR}) \times 100 \%
$$

Description:

$\mathrm{Pp} \quad=$ the actual energy percentage of the respective food groups to EAR

$\mathrm{Ep} \quad=$ the total actual energy in the food group $\mathrm{p}$

EAR = the energy adequacy ratio which is $2,150 \mathrm{kcal} / \mathrm{cap} /$ day

$\mathrm{p} \quad=$ the food group $1,2,3, \ldots, 9$

The score of Desirable Dietary Pattern (DDP) is quantified by comparing the EAR score and the normative DDP score. Therefore, we should quantify the EAR score by multiplying the energy percentage to EAR (\%EAR) by the determined weight of the food group (Food Security Bureau [Badan Ketahanan Pangan], 2015).

$$
\text { EAR score }=\mathrm{Pp} \times \mathrm{Bp}
$$

Description:

EAR score $\quad=$ the score of Energy Adequacy Ratio

$\mathrm{Pp} \quad=$ the actual energy percentage of the food group $\mathrm{p}$ to EAR

$\mathrm{Bp} \quad=$ the weight of the food group

$\mathrm{p} \quad=$ the food group $1,2,3, \ldots, 9$

The score of Desirable Dietary Pattern (DDP) is the reflection of EAR score itself, it just needs to be compared with the limit of the maximum DDP score (normative DDP). In this case, the EAR score is higher than the normative DDP score, so DDP normative can be taken as the actual DDP score. On the other hand, if the EAR score is under the normative DDP score, the EAR score will be taken as the actual DDP score. This quantity and quality are closely related in improving food diatery patterns. Therefore, to check whether the quantity or quality of food diatery is in accordance with the recommended norms, each statistical difference test is used as follows:

\section{The Actual Average Energy Consumption Quantity Test}

This kind of $t$ test is needed to see whether the actual average energy consumption has been fulfilled its normative energy quantity or not.

$$
\mathrm{t}=\frac{\overline{\mathrm{x}}-\mu \circ}{s / \sqrt{n}}
$$

Description:

$\bar{x}=$ the average of household diatery

$\mathrm{s}=$ standard of deviation from the samples

$\mathrm{n}=$ the number of samples

$\mu=$ the actual energy quantity parameter testing 
Hypothesis:

Ho: $\mu \geq 2,150$

H1: $\mu<2,150$

If $t_{\text {count }} \geq t_{\text {table }}$ at a certain level of significance, then $H_{0}$ is rejected and $H_{1}$ is accepted. If $t_{\text {count }}<$ $t_{\text {table }}$ at a certain level of significance, then $\mathrm{H}_{1}$ is rejected and $\mathrm{H}_{0}$ is accepted.

\section{The Actual Average of Desirable Dietary Pattern Score Test}

The last stage is to do a statistical difference test on the average DDP score, that is to test whether the household actual DDP score has reached the normative DDP score or not.

Description:

$$
\mathrm{t}=\frac{\overline{\mathrm{x}}-\mu \circ}{s / \sqrt{n}}
$$

$\overline{\mathrm{x}}=$ the average score of Desirable Dietary Pattern

$\mathrm{s}=$ standard of deviation from the samples

$\mathrm{n}=$ the number of samples

$\mu=$ the actual DDP parameter testing

Hypothesis:

Ho: $\mu=100$

$\mathrm{H} 1: \mu<100$

If $t_{\text {count }} \geq t_{\text {table }}$ at a certain level of significance, then $H_{0}$ is rejected and $H_{1}$ is accepted. If $t_{\text {count }}<$ $t_{\text {table }}$ at a certain level of significance, then $\mathrm{H}_{1}$ is rejected and $\mathrm{H}_{0}$ is accepted.

\section{The Analysis of the Food Dietary Patterns Factors}

To analyze the factors that influence food dietary patterns is using multiple regression. The regression model used in this research is as follows:

$\mathrm{Y}=\beta \_0+\beta \_1 \mathrm{X} \_1+\beta \_2 \mathrm{X} \_2+\beta \_3 \mathrm{X} \_3+\beta \_4 \mathrm{X} \_4+\beta \_5 \mathrm{X} \_5+\beta \_6 \mathrm{X} \_6+\beta \_1 \mathrm{D} \_1+\mathrm{e}$

Description:

$\mathrm{Y} \quad=$ Food dietary patterns (DDP Score)

$\mathrm{X} \_1 \quad=$ Education (year)

$\mathrm{X} \_2=$ The number of household members (people)

$\mathrm{X} \_3=$ Age (year)

$\mathrm{X} \_4=$ The Household income per capita (IDR/month)

X_5 = The Rice Price (IDR/kg)

X_6 = The Recipient of Government aids (IDR/Rt)

D_1 = Dummy variabel for the main occupation type of the household members

D1 = 1 Household which the main occupation is agricultural sector

Do $=0$ Household which the main occupation is out of agricultural sector

$\beta \_0=$ The Constant

$\beta \_\mathrm{i}=$ The regression coefficient of each variable

e $\quad=$ error 
To gain the best regression result, it must fulfill:

1. $\mathrm{R}^{2}$ Test (Coefficient of Determination): Calculating the proportion or the total percentage of variation in $\mathrm{Y}$ which is explained by the model.

2. F test: It was conducted to see the influence of the independent variables as a whole on the dependent variable. This kind of test was also carried out by comparing the value of $\mathrm{F}_{\text {count }}$ with $\mathrm{F}_{\text {table. }}$.

3. $t$ test : It was conducted to see the significant effects of the independent variable partially on the dependent variable. This test was also carried out by comparing $t$ count with $t_{\text {table. }}$.

\section{RESULT AND DISCUSSIONS}

\section{The Analysis of Household Food Dietary Patterns}

Food dietary patterns are the food consumed including energy sources and other nutrients in order to fulfill the food needs and the nutrients balance, both in terms of quantity and quality (Food and Agriculture Organization of the United Nations, 2020). The quantity is the total volume of food consumed per capita, which was calculated from the aspect of energy fulfilment. Meanwhile, the quality is the food dietary in the aspect of food variety and it was also monitored by DDP score (Sirajudin et al., 2018). The government has determined the target of output achieving for both quantity and quality food consumptions. The conceptual quantity was indicated to be successful if the average consumption of people per day is at least 2,150 kcal. Meanwhile, the quality of food was measured by the achievement of the DDP score, which is 100 (Food Security Bureau, 2015). However, a DDP score of 100 will not be reached when the quantity of food energy consumption has not fulfilled the minimum recommendation, that is $2,150 \mathrm{kcal}$ (United Nations Environment Program, 2012). Thus, this research calculated the results of the assessment on food dietary not only for quality (DDP) but also for quantity (EAR), to support the achievement of food consumption patterns improvement.

\section{The Analysis of Household Energy Adequacy Numbers}

The average of energy consumption at the research location, in table 1 , it is $1,826.50$ $\mathrm{kcal} / \mathrm{cap} / \mathrm{day}$. This result was still under the normative Energy Consumption Rate that is 2,150 kcal / cap / day. Based on the results of the average difference test, it showed the significant results with a normative energy consumption, it is $2,150 \mathrm{kcal} / \mathrm{cap} /$ day ( $\mathrm{t}_{\text {count }}$ $(9.080) \geq t_{\text {table }}(2.657)$ at $99 \%$ trust level.

TABLE 1. THE ENERGY CONSUMPTION AND THE LEVEL OF HOUSEHOLD ENERGY

\begin{tabular}{lcc}
\hline Variable & Energy Consumption (kcal/capita/day) & Energy Adequacy Ratio (\%EAR) \\
\hline Minimum & $1,057.27$ & 49.18 \\
Maximum & $2,264.97$ & 105.35 \\
Average & $1,826.50$ & 84.71 \\
Normative & 2,150 & 100.00 \\
$\mathrm{t}-$ Test $\left(\mathrm{t}_{\text {table }}=2.657\right)$ & $\left(\mathrm{t}_{\text {count }}=9.080\right)$ & \\
\hline
\end{tabular}


While in the calculation of the percentage level of energy consumption (\% EAR) the average of household has only reached $84.71 \%$ EAR, it was still less $15.29 \%$ to be able to reach $100 \%$ EAR as the recommendation. The analysis results of calorie quantity in this research area are still low.

Geographically, the condition of this research area is an arid area, that is why the agriculture cannot develop properly. As mentioned from the news (The Public Sovereignty Newspaper [Kedaulatan Rakyat], 2019), it explained that the drought in Wukirsari Village at the end of 2019 attacked 19 households. According to Wukirsari Headman, this incident was the worst thing in recent years. Furthermore, the Head of Farmer Group Association in Wukirsari said that the long drought has caused a decrease of rice productivity which normally reached 6.8 tons per hectare, while in drought conditions it only reached 4.6 tons per hectare (Tribun Jogja, 2014). The change of rainfall and extreme climate, such as drought, has an impact to the risk of production decreasing up to 10 percent. The production decreasing will also affect the level of people's purchasing food power (Ariani, 2014). Moreover, it was also described that the household energy consumption in the insecurity areas are always lower than common households. The analysis results in previous studies indicated that the household energy consumption in the insecurity areas are not more than $72 \%$ of the adequacy standard (Ariani \& Hardono, 2005).

\section{The Analysis of Household Desirable Dietary Pattern}

The average of the desirable dietary pattern at the research location, in table 2, is 60.62 with the results of the DDP score range from a minimum of 47.10 to a maximum of 79.19. This result was certainly different from the normative DDP, because the tests performed that $t_{\text {count }}$ (36.63) was much higher than $t_{\text {table }}(2.657)$ at the $99 \%$ trust level. The desirable dietary patterns in this research area has only reached 60.62 from the normative DDP of 100. This means that the quality of food dietary at Wukirsari, as a food insecurity areas, is still far from the standard.

\section{TABIE 2. THE SCORE OF HOUSEHOLD DESIRABIE DIETARY PATERN}

\begin{tabular}{|c|c|}
\hline Variable & The Score of Actual Desirable Dietary Pattern (DDP) \\
\hline Minimum & 47.10 \\
\hline Maximum & 79.19 \\
\hline Average & 60.62 \\
\hline Normative & 100 \\
\hline $\mathrm{t}$-Test $\left(\mathrm{t}_{\text {tabel }}=2.657\right)$ & $\left(t_{\text {count }}=36.63\right)$ \\
\hline
\end{tabular}

Source: The primary data processed, 2019

Food quality as indicated by the DDP score was influenced by income (Babalola \& Isitor, 2014). This is appropriate to the conditions of Wukirsari, where most of the population are still classified as poor. The findings during the research indicated the condition of the households. Most of them worked as rainfed farmers, farm hands or seasonal traders at tourist sites. The uncertainty of the income caused them to be categorized as poor, indirectly it was influenced their ability to buy the various foodstuffs and fulfill the nutritional standards. 


\section{The Analysis of Factors Affecting Food Dietary Patterns}

The findings showed that the estimation of model used to get coefficient of determination $\left(\mathrm{R}^{2}\right)$ is 0.235 . It can be said that all the independent variable $(\mathrm{X})$ which were put to the regression model were only able to describe the dependent variable $(\mathrm{Y})$ around $23.5 \%$, while the remaining $76.5 \%$ were described as any other independent variables which were not included to the model. At the same time, the value of $\mathrm{F}_{\text {count }}(2.410)$ was greater than $\mathrm{F}_{\text {table }}(2.11)$ and the probability value was less than 0.05 at the $95 \%$ trust level, then $\mathrm{H}_{0}$ was rejected and accepted $\mathrm{H}_{1}$. It can be concluded that all the independent variables $(\mathrm{X})$ in the model have a significant effect to the dependent variable (Y) (Table 3). Thus, the model used in this research was described as follows:

$$
Y=11,691+2,272 X_{1}-0,452 X_{2}-0,042 X_{3}+0,000 X_{4}+0,005 X_{5}-0,108 X_{6}+0,010 X_{7}+e
$$

\section{TABEL 1. ESTIMATED RESULTS OF REGRESSION FACTORS AFFECTING FOOD CONSUMPTION PATTERNS OF HOUSEHOLDS}

\begin{tabular}{lccc}
\hline \multicolumn{1}{c}{ Variable } & Coefficient of Regression & $\mathbf{t}_{\text {count }}$ & Sig. \\
\hline The constant & 11.691 & 0.370 & 0.71 \\
Education $\left(X_{1}\right)$ & $2.272^{* *}$ & 2.120 & 0.03 \\
The number of household members $\left(X_{2}\right)$ & -0.452 & -0.425 & 0.67 \\
Age $\left(X_{3}\right)$ & -0.042 & -0.343 & 0.73 \\
Household income per capita $\left(X_{4}\right)$ & 0.000 & 0.488 & 0.62 \\
Rice Price $\left(X_{5}\right)$ & 0.005 & 1.414 & 0.16 \\
The Recipient of Government aids $\left(X_{6}\right)$ & -0.108 & -0.405 & 0.68 \\
Main Occupation $\left(D_{1}\right)$ & 0.910 & -0.331 & 0.74 \\
\hline
\end{tabular}

Dependent Variable : Food Dietary Patterns (Actual DDP Score)

$\mathrm{R}^{2} \quad: 0.235$

$\mathrm{F}_{\text {count }} \quad: 2.410$

Prob $\quad: 0.032$

: Real at the level of trust $99 \%(\alpha=0.01), \mathrm{t}_{\text {table }}=2.669$

** : Real at the level of trust $95 \%(\alpha=0.05), \mathrm{t}_{\text {table }}=2.004$

* : Real at the level of trust $90 \%(\alpha=0.10), t_{\text {table }}=1.673$

The influences of the education variable, number of household members, age of the head of the family, income per capita, price of rice, recipients of assistance and types of main work are partially explained as follows.

\section{Education $\left(\mathrm{X}_{1}\right)$}

Education had a significant influence on food security (Mutisya et al., 2016). Low education caused a lower possibility of getting a job. This factor affected the household income, which also directly influenced people's purchasing power of nutritious food (Bhandari \& Smith, 2000).

The education variable affected the food dietary patterns at the $95 \%$ trust level. It can be said that the value of $t_{\text {count }}(2.120)$ was greater in $t_{\text {table }}(2.004)$. Having a coefficient value 2.272 showed that the higher one year of formal education was achieved, the DDP score can be increased around 2.272 . 
The intervention of Government to improve the quality of foods in the insecurity areas, especially in Wukisari was by increasing the education both physically and nonphysically, such as adding more school facilities, and also providing public trainings.

\section{The Number of Household Members $\left(\mathrm{X}_{2}\right)$}

The number of household members was the people in one household. Based on the statistical test, the variable number of household members did not affected significantly to the household food dietary patterns. This happened because the value of $t_{\text {count }}(0.425)$ was smaller than the value of $\mathrm{t}_{\text {table }}(1.673)$ at the $90 \%$ trust level.

This reasearch findings was suitable to the previous research entitled The Factors Affecting Family Consumption Patterns of Civil Servant Teachers (ASN) in South Minahasa District, it was mentioned that the number of family members did not affected significantly the family food consumption. So, it can be concluded that the increasing of family members will not necessarily have an impact on the family's consumption pattern, thus the decreasing of family members will also not affect the consumption patterns that have been formed so far. It was related to the family income. The more family income, then the increasing family members will not significantly change the food dietary pattern, and the opposite happened (Lintang et al., 2019). In addition, some of the family members in that village lived temporarily in the Yogyakarta. They usually return to their village on weekends, or at least once every 3 days.

\section{The Head of Family Age $\left(\mathrm{X}_{3}\right)$}

The age was the number of respondents age. Based on the results of statistical tests, it showed that the age variable did not affect the household food dietary patterns significantly. It was happened because the value of $t_{\text {count }}(0.343)$ was smaller than the value of $t_{\text {table }}(1.673)$ at the $90 \%$ trust level.

The findings of this research was related to the previous research entitled Food Dietary Patterns in Farmers' Households in Ruguk, Ketapang, South Lampung, which stated that the age variable partially has no effect on food quality or DDP value (Arlin et al., 2017).

In another study, the age has a significant negative effect on the income (Ariska \& Prayitno, 2019), which directly influenced the quality of food. However, the actual conditions at the research location explained that the head of the family was already in an unproductive age (over 60 years), so the children were responsible for ensuring their parents food. In addition, food could also be obtained from the neighbors and relatives who were staying away. This phenomenon caused the age has no effect on the quality of household food dietary.

\section{The Households Income per Capita $\left(\mathrm{X}_{4}\right)$}

The households income percapita variable number did not affected significantly to the household food dietary patterns. This happened because the value of $\mathrm{t}_{\text {count }}(0.488)$ was smaller than the value of $t_{\text {table }}(1.673)$ at the $90 \%$ trust level. This findings did not related to the previous researches which said that the income affected the food quality (Damora et al., 2008; Sanjaya \& Dewi, 2017). This phenomenon happened because the actual condition of the research area. It has been described briefly in the age variable. The actual condition described 
that the food dietry patterns in that research area do not always come from the purchasing, but also from relatives, children, and closest neighbors.

\section{The Rice Price $\left(\mathrm{X}_{5}\right)$}

The rice price variable did not have a significant impact to the household food dietary patterns. This is also happened because the value of $t_{\text {count }}(1.414)$ was smaller than the value of $\mathrm{t}_{\text {table }}(1.673)$ at the $90 \%$ trust level. This findings did not related to the previous studies which stated that the increasing of commodity prices will cause commodity demands (Riyani et al., 2018). Moreover, it also changed the food dietary patterns (Saputra et al., 2019). However, the actual condition of the research location was different. The most rice that consumed by the people came from their own harvest which was stored for a period of a year. In addition, the people also received some assistances from their own family and also from the government.

\section{The Recipient of Government Aids $\left(\mathrm{X}_{6}\right)$}

Since the value of $t_{\text {count }}(0.405)$ was smaller than the value of $t_{\text {table }}(1.673)$ at the $90 \%$ trust level, it can be concluded that this variable did not have a significant effect. The aids provided by the Government has not been able to increase the household consumption in the research location (Nasution \& Zuraya, 2020). Several respondents and village stakeholders explained that the amount of Government aids could not significantly improve the food quality. Furthermore, they also said that it was only used to cover their debts.

\section{The Main Occupation of The Head of Family $\left(\mathbf{X}_{7}\right)$}

The value of $t_{\text {count }}(0.331)$ was smaller than the value of $t_{\text {table }}(1.673)$ at the $90 \%$ trust level. Thus, this variable did not have a significant impact to the food dietary patterns. It can be concluded that whatever their occupation, whether working in the agricultural or nonagricultural sectors, has no influence on their food consumption. It was caused by the income, which was not much different, around IDR 600,000, to IDR 1,000,000,- each month.

\section{CONCLUSIONS AND SUGGESTIONS}

Based on the research findings, it can be concluded that the food dietary patterns in Wukirsari has not yet diverse. This was proved by the results of the DDP score analysis of 60.62, while the normative DDP score was 100 . The low DDP score was caused by the low energy quantity average, it was around 1,826 kcal / cap / day with an Energy Adequacy Ratio (EAR), 84.71 percent.

The factors that has partially significant influences to the household dietary consumption patterns in food insecurity areas in Wukirsari was the level of education. Meanwhile, the other factors such as the number of household members, age of the head of the household, income per capita, price of rice, recipients of aids, and the main occupation of the head of the family have a significant effect on food consumption patterns, but not partially significant.

The interventions that can be carried out based on the findings is the improving of the education quality for people in food insecurity areas, particularly in Wukirsari, Imogiri, 
Bantul. Improving the quality of education can be achieved by building some physical schools, subsidizing school fees and improving the quality of teaching and learning activities. In addition, other policy that can be carried out related to education is providing non-formal training in order to increase the chances of getting more jobs for the people there.

\section{ACKNOWLEDGEMENTS}

The author would like thank to the Ministry of Research, Technology and Higher Education, Department of Agribusiness Universitas Muhammadiyah Yogyakarta, Regional Planning \& Development Agency, Yogyakarta, and residents of Wukirsari, Imogiri, Bantul.

\section{REFERENCES}

Andri, K. B. (2019, May 9). Menjaga Ketahanan Pangan dengan Diversifikasi Pangan Lokal [Maintaining Food Security with Local Food Diversification]. Republika, Kolom. https://www.republika.co.id/berita/kolom/wacana/19/05/09/pr8p3k453-menjagaketahanan-pangan-dengan-diversifikasi-pangan-lokal

Ariani, M. (2014). Analisis Konsumsi Pangan Tingkat Masyarakat Mendukung Pencapaian Diversifikasi Pangan [Analysis of Community Level Food Consumption Supports Achievement of Food Diversification]. Gizi Indonesia, 33(1), 20-28. https://doi.org/10.36457/gizindo.v33i1.84

Ariani, M., \& Hardono, G. S. (2005). Perubahan Pola Konsumsi Pangan Rumahtangga Rawan Pangan [Changes in Food Consumption Patterns for Food Vulnerable Households]. Gizi Indonesia, 28(1), 9-21. https://persagi.org/ejournal/index.php/Gizi_Indon/issue/view/6

Ariska, P. E., \& Prayitno, B. (2019). Pengaruh Umur, Lama Kerja, dan Pendidikan terhadap Pendapatan Nelayan di Kawasan Pantai Kenjeran Surabaya Tahun 2018 [The Effect of Age, Length of Work, and Education on Fishermen's Income in the Kenjeran Beach Area, Surabaya in 2018]. Economie, 1(1), 38-47. https://journal.uwks.ac.id/index.php/economie/article/view/820

Arlin, N. A., Arifin, B., \& Suryani, A. (2017). Pola Konsumsi Pangan pada Rumah Tangga Petani Di Desa Ruguk Kecamatan Ketapang Kabupaten Lampung Selatan [Food Consumption Patterns in Farmers Household in Ruguk Village, Ketapang District, South Lampung Regency]. Journal of Agribusiness Science, 5(2), 206-210. https://core.ac.uk/download/pdf/297870754.pdf

Babalola, D. A., \& Isitor, S. U. (2014). Analysis of the Determinants of Food Expenditure Patterns among Urban Households in Nigeria: Evidence from Lagos State. IOSR Journal of Agriculture and Veterinary Science, 7(5), 71-75. https://doi.org/10.9790/2380-07537175

Badan Ketahanan Pangan [The Food Security Bureau]. (2015). Panduan Perhitungan Pola Pangan Harapan (PPH) [Guideines for Desirable Dietary Pattern]. In Kementerian Pertanian. Badan Ketahanan Pangan, Kementerian Pertanian.

Badan Ketahanan Pangan [The Food Security Bureau]. (2017). Analisis Pola Konsumsi dan Kebutuhan Konsumsi Pangan [Analysis of Consumption Patterns and Food 
Consumption Needs]. Kementerian Pertanian. http://bkp.pertanian.go.id/analisispola-konsumsi-dan-kebutuhan-konsumsi-pangan

Badan Ketahanan Pangan dan Penyuluhan DIY [The Food Security and Extension Bureau DIY]. (2016). Peta Rawan Pangan dan Gizi Daerah Istimewa Yogyakarta 2016 (Vol. 1) [Map of Food and Nutrition Hazard Daerah Istimewa Yogyakarta 2016]. https://bkpp.jogjaprov.go.id/download/index/3/ kategori/Data+dan+Informasi

Badan Pusat Statistik [The Central Bureau of Statistics]. (2017). Persentase Penduduk Miskin Maret 2019 Sebesar 9,41 Persen [Percentage of Poor Population in March 2019, amounting to 9.41 Percent]. Badan Pusat Statistik. https://doi.org/10.1055/s-20081040325

Badan Urusan Logistik [The Indonesia Logistics Bureau]. (2018). Ketahanan Pangan. Www.Bulog.Co.Id. http://www.bulog.co.id/ketahananpangan.php

Bhandari, R., \& Smith, F. J. (2000). Education and Food Consumption Patterns in China: Household Analysis and Policy Implications. Journal of Nutrition Education, 32(4), 214-224.

https://www.sciencedirect.com/science/article/abs/pii/S0022318200705590

Damora, A. S. U., Anwar, F., \& Heryatno, Y. (2008). Pola Konsumsi Pangan Rumah Tangga Petani Hutan Kemasyarakatan Di Kabupaten Lampung Barat [Community Forest Farmers' Household Food Consumption Patterns in West Lampung Regency]. Jurnal Gizi Dan Pangan, 3(3), 227. https://doi.org/10.25182/jgp.2008.3.3.227-232

Food and Agriculture Organization. (2007). An Introduction to the Basic Concepts of Food Security. In Food Security Information for Action (Practical Guides). https://doi.org/10.1057/9780230589780_35

Food and Agriculture Organization of the United Nations. (2020). The State of Food Security and Nutrition in the World (Transforming Food Systems for Affordable Healthy Diets). In IEEE Journal of Selected Topics in Applied Earth Observations and Remote Sensing. Food and Agriculture Organization of the United Nations. https://www.who.int/publications/m/item/state-of-food-security-and-nutrition-inthe-world-2020

Kedaulatan Rakyat [The People's Sovereignty Newspaper]. (2019, September 21). Dampak Kekeringan di Bantul Terus Meluas [The impact of the drought in Bantul is increasingly widespread]. Berita Lokal DIY. https://www.krjogja.com/beritalokal/diy/bantul/dampak-kekeringan-di-bantul-terus-meluas/

Kostakis, I. (2014). The Determinants of Households' Food Consumption in Greece. International Journal of Food and Agricultural Economics, 2(2), 17-28. https://doi.org/10.22004/ag.econ.168576

Kuzmin, E. A. (2016). Sustainable food security: Floating balance of markets. International Journal of Economics and Financial Issues, 6(1), 37-44. https://www.econjournals.com/index.php/ijefi/article/viewFile/1575/pdf

Lintang, S., Engka, D. S. ., \& Tolosang, K. D. (2019). Faktor-Faktor Yang Mempengaruhi Pola Konsumsi Keluarga Guru Aparatur Sipil Negara (ASN) Di Kabupaten Minahasa Selatan (Studi SMP Negeri 1, Sma Negeri 1, Smk Negeri 1 Amurang) [Factors 
Influencing Consumption Patterns of Family Teachers of State Civil Servants, in South Minahasa District]. Jurnal Berkala Ilmiah Efisiensi, 19(04), 48-59. https://ejournal.unsrat.ac.id/index.php/jbie/article/view/26186/25820

Mutisya, M., Ngware, M. W., Kabiru, C. W., \& Kandala, N. bakwin. (2016). The Effect of Education on Household Food Security in Two Informal Urban Settlements in Kenya: a Longitudinal Analysis. Food Security, 8(4), 743-756. https://doi.org/10.1007/s12571-016-0589-3

Nasution, D. D., \& Zuraya, N. (2020). Bantuan Pemerintah Belum Mampu Dongkrak Konsumsi [Government assistance has not been able to increase consumption]. Https://Republika.Co.Id/. https://republika.co.id/berita/qhjpes383/ekonombantuan-pemerintah-belum-mampu-dongkrak-konsumsi

Riyani, Darsono, \& Ferichani, M. (2018). Analisis Permintaan Ekspor Komoditas Pertanian Indonesia oleh Pasar Tiongkok [Analysis of Export Demand for Indonesian Agricultural Commodities by the Chinese Market]. AGRARIS: Journal of Agribusiness and Rural Development Research, 4(2), 120-127. https://doi.org/10.18196/agr.4267

Sanjaya, I. K. A. P., \& Dewi, M. H. U. (2017). Analisis Pengaruh Pendapatan, Jumlah Anggota Keluarga dan Pendidikan terhadap Pola Konsumsi Rumah Tangga Miskin Di Desa Bebandem, Karangasem [Analysis of the Effect of Income, Number of Family Members and Education on Consumption Patterns of Poor Households in Bebandem Village, Karangasem]. E-Jurnal EP Unud, 6 [8], 6(8), 1573-1600. https://ojs.unud.ac.id/index.php/eep/article/view/29983/19560

Saputra, M. F., Firdaus, M., \& Novianti, T. (2019). Pola Konsumsi Pangan Non Karbohidrat pada Provinsi Tahan dan Rawan Pangan (Provinsi Kalimantan Timur dan Nusa Tenggara Timur) Tahun 2017 [Consumption Pattern of Non-Carbohydrate Food in Food Resistant and Insecure Provinces]. AGRARIS: Journal of Agribusiness and Rural Development Research, 5(2), 129-139. https://journal.umy.ac.id/index.php/ag/article/view/6269/4840

Sirajudin, Surmita, \& Astuti, T. (2018). Survey Konsumsi Pangan [Food Consumption Survey] (A. Suhardianto (ed.)). Pusat Pendidikan Sumber Daya Manusia Kesehatan, Badan Pengembangan dan Pemberdayaan Sumber Daya Manusia Kesehatan [Center for Health Human Resources Education, Agency for the Development and Empowerment of Health Human Resources.]. http://bppsdmk.kemkes.go.id/pusdiksdmk/wp-content/uploads/2018/09/SurveyKonsumsi-Pangan_SC.pdf

Tribun Jogja. (2014, September 21). Sawah Petani Wukirsari Mulai Mengiring Kesulitan Air [Farmers' Rice Fields in Wukirsari Start Drying Due to Water Difficulties]. Kolom Bantul. https://jogja.tribunnews.com/2014/09/21/sawah-petani-wukirsari-mulaimengiring-kesulitan-air

United Nations Environment Programme. (2012). The Critical Role of Global Food Consumption Patterns in Achieving Sustainable Food Systems and Food for All. In UNEP (1st $\quad$ ed.). https://wedocs.unep.org/bitstream/handle/20.500.11822/25186/1/Food_Consum ption_Patterns.pdf 